Francke, A.L., Garssen, B., Luiken, J.B., Schepper, A.M.E. de, Grypdonck, M., Huijer Abu-Saad, H. Effects of a nursing pain programme on patient outcomes. Psycho-Oncology: 1997, 6, $302=$

\begin{tabular}{|l|l|}
\hline $\begin{array}{l}\text { Postprint } \\
\text { Version } \\
\text { Journal website }\end{array}$ & 1.0 \\
\hline Pubmed link & $\underline{\underline{\mathrm{TRY}}=0}$ \\
\hline DOI & $\underline{\mathrm{http} / / / \text { wwww.ncbi.nlm.nih.gov/pubmed/9451749 }}$ \\
\hline $10.1002 /(\mathrm{SICI}) 1099-1611(199712) 6: 4<302:: A I D-P O N 284>3.0 . C O ; 2-\mathrm{D}$ \\
\hline
\end{tabular}

This is a NIVEL certified Post Print, more info at http://www.nivel.eu

\title{
EFFECTS OF A NURSING PAIN PROGRAMME ON PATIENT OUTCOMES
}

\author{
ANNEKE L. FRANCKE ${ }^{1 *}$, BERT GARSSEN ${ }^{1}$, J. BART LUIKEN ${ }^{1}$, ANDREA M.E. DE \\ SCHEPPER $^{1}$, MIEKE GRYPDONCK ${ }^{2}$ AND HUDA HUIJER ABU-SAAD ${ }^{3}$ \\ ${ }^{1}$ Helen Dowling Institute for Biopsychosocial Medicine Rotterdam; \\ ${ }^{2}$ Department of Nursing Science, University of Utrecht, and Department of Nursing Science, \\ Catholic University of Gent; \\ ${ }^{3}$ Department of Nursing Science, University of Limburg, Maastricht, The Netherlands \\ *Correspondence to: Anneke Francke, NIVEL, PObox 1568, 3500 BN Utrecht, The \\ Netherlands.
}

\begin{abstract}
SUMMARY
The effectiveness of a continuing pain education program, directed to surgical cancer nurses, was investigated in a pretest posttest controlled intervention study. ANCOVA for repeated measures revealed that the programme resulted in a lower pain intensity of surgical colon and breast cancer patients $(p=0.02)$. However, no effects were found on pain duration, sleepless hours as a result of pain, state anxiety, mood disturbances, and duration of hospitalization. It is assumed that because the pain CE programme had a moderate impact on pain intensity, this had no consequences for the other outcome variables mentioned.
\end{abstract}

\section{INTRODUCTION}

Adequate pain relief for surgical cancer patients is of great importance, for humane as well as for medical reasons. Postoperative pain may reinforce anxiety and other mood disturbances, compromise patient outcomes, and result in longer recovery periods (Acute Pain Management Guideline Panel, 1992; Bonica, 1987). However, several researchers indicated that in practice pain is often insufficiently relieved (e.g., Abbott et al., 1990; Carr, 1990). Paice et al., (1991), for instance, interviewed a group of surgical cancer patients and found that $76 \%$ had mild to severe pain at the time of the interview.

One of the reasons for insufficient pain relief may be that nurses do not always assess the presence and characteristics of pain (Paice et al., 1991; Grossman et al., 1991). In addition, many nurses administer analgesics irregularly and in ineffective dosages (Carr, 1991; Closs, 1990). Furthermore, nurses often do not make optimum use of nonpharmacological interventions, like relaxation, distraction and massage (Dalton, 1989).

Continuing education (CE) seems to be a way to bridge these gaps. However, of the studies on pain CE programmes for nurses (for an overview, see Francke et al., 1996a), only four have examined whether patients are also affected by the CE programme (Degner, et al., 1982; Foglesong, 1983; Foglesong et al., 1987; Sofaer, 1984). In the Foglesong (1983) and Foglesong et al. (1987) studies it was concluded that surgical patients admitted after the 
Francke, A.L., Garssen, B., Luiken, J.B., Schepper, A.M.E. de, Grypdonck, M., Huijer Abu-Saad, $\mathrm{H}$. Effects of a nursing pain programme on patient outcomes. Psycho-Oncology: 1997, 6, 302 310

programme had less pain complaints. Sofaer (1984) found that surgical patients admitted after nurses participated in CE on pain had lower pain intensity and fewer hours of pain on postoperative days 0 and 1. Degner et al. (1982) established after a pain CE programme for nurses, that oncological patients had more pain-free periods, probably as a result of changes in nurses' pharmacological pain management.

In view of the limited number of studies on the effects of nursing pain programmes, further research in this field is needed. Within this scope, a CE programme on pain assessment and management was evaluated in both nurses and patients. In Francke (1996) and Francke et al. (1996b and 1997) the effects of the CE pro- gramme on nurses were described. To summarize, the programme led to an increase in the quality of nurses' pain assessment practices. In addition, the programme resulted in an increase in the quality of physical and relaxation interventions (e.g. use of a relaxing foot massage and structured relaxation exercises). Furthermore, the programme led to an increase in the duration and quality of psychosocial interventions (e.g. provision of information and emotional support). The programme also led to an improvement in the quality of nurses' analgesic administrations, and to an increase in the quantity of nonopioids administered. Whether the CE programme had also consequences for patients is discussed in this article. The following research questions are addressed:

Does the CE programme result in:

a decrease in patients' postoperative pain?

More specifically formulated,

(a) a decrease in the intensity of postoperative pain?

(b) a decrease in pain duration during the day?

(c) a decrease in the number of sleepless hours as a result of pain?

2. a decrease in patients' state anxiety and mood disturbances?

3. a decrease in patients' length of hospitalization?

\section{METHOD}

\section{Design}

Effects of the programme were measured in a pre-test post-test control group design, in which randomization took place on 'ward level'. In each of the five participating hospitals, one ward was randomly allocated to the experimental condition (CE programme for nurses) and another ward to the control condition (no CE programme for nurses). Data from patients in both conditions were collected in two measurement periods:

- 0-3 months before the programme (period M1);

- 3-6 months after the programme (period M2).

\section{Sample}

Five Dutch general hospitals, chosen on the basis of geographical proximity, participated in the study. In each hospital, two surgical wards were involved that hospitalized both cancer and noncancer patients.

Effects of the CE programme were measured in 152 surgical cancer patients. Patients studied met the following inclusion criteria: being hospitalized for a curative resection of colon or breast cancer; having a life expectancy of more than 6 months; active command of the Dutch language. The 152 patients who participated in the study were spread over four groups:

- a group admitted to the 'experimental wards' in period M1 ( $n=15$ colon cancer patients and 27 breast cancer patients);

- a group admitted to the 'experimental wards' in period M2 $(n=11$ colon cancer patients and 30 breast cancer patients). This group concerns the patients attended by nurses after the CE program; 
Francke, A.L., Garssen, B., Luiken, J.B., Schepper, A.M.E. de, Grypdonck, M., Huijer Abu-Saad, $\mathrm{H}$. Effects of a nursing pain programme on patient outcomes. Psycho-Oncology: 1997, 6, 302 310

- a group admitted to the 'control wards' in period M1 ( $n=15$ colon cancer patients and 26 breast cancer patients);

- a group admitted to the 'control wards' in period M2 ( $n=13$ colon cancer patients and 15 breast cancer patients).

Measurements were restricted to only two patient categories (surgical colon and breast cancer patients) to increase the chance of valid conclusions.Particularly these two patient categories were selected because of the high prevalence of colon and breast cancer, which facilitates patient recruitment. Another reason for this selection was that the surgical treatment of colon and breast cancer is often connected with pain (Daut and Cleeland, 1982).

Permission for patient recruitment was obtained from the medical specialists and ethical committees. Patients who met the inclusion criteria (see before) were asked to participate through head nurses or other executive nurses. In addition to this direct request, the patients were given an information letter in which goals and procedures of the study were explained. From all patients informed consent was obtained. None of the patients who consented to participate in the study dropped out. (For comments on non-cooperation of patients, see section 'Discussion'.)

\section{Intervention}

The CE programme on pain assessment and management consisted of eight weekly 3-hour sessions. A follow-up meeting was held 4 months after the end of the programme.

Programme items dealt with were:

(i) characteristics of pain (e.g. its uniqueness for every patient and its subjectivity) and assessment of pain (e.g. pain history taking and the use of rating scales);

(ii) psychosocial interventions (e.g. provision of psychosocial support and information);

(iii) physical and relaxation interventions (e.g. massage, and use of relaxation and distraction techniques); (iv) pharmacological pain management (e.g. rationale of scheduled analgesics, and real risks of side-effects).

Approximately 3 contact hours were devoted to programme item (i), 7.5 contact hours to item (ii), 6 contact hours to item (iii) and 4.5 contact hours to item (iv). Remaining contact hours had a more general character (e.g. group evaluations).

Elaboration of the above themes was related to the surgical-oncological background of participants.This resulted in more emphasis on acute rather than chronic pain assessment and management.

Various didactic strategies were used: introductions by the teachers, discussions in the group as a whole and in small groups, practical exercises and provision of relevant literature.

In principle, all the qualified nurses of a ward team (including head nurses and team leaders) participated together in the program. Only in exceptional cases (e.g. protracted illness or pregnancy) was an exception made. Coordinating head nurses and division managers who were not directly involved in patient care did not participate. The programme took place in a room in the participating hospital and was presented by two instructors: one with a professional background in nursing and education and the other with a background in adult education.

\section{Instruments}

Pain intensity was measured with the single item Numerical Rating Scale. This scale ranges from 0 (no pain at all) to 10 (worst pain), and has been established as valid and reliable (Scott and Huskusson, 1976).

For measuring the pain duration during the day and the number of sleepless hours as a result of pain, two relevant items of the Dutch version (Verkes et al., 1989) of the McGill Pain Questionnaire Quality of Life-scale (Melzack, 1975) were used. The reliability and the validity of the Dutch version have shown to be satisfactory (Verkes et al., 1989; Vanderiet et al., 1987).

For measuring state anxiety, four items of the Dutch version (Van der Ploeg et al., 1980) of the State-Trait and Anxiety Inventory (Spielberger et al., 1970) were used. The Dutch 
Francke, A.L., Garssen, B., Luiken, J.B., Schepper, A.M.E. de, Grypdonck, M., Huijer Abu-Saad, $\mathrm{H}$. Effects of a nursing pain programme on patient outcomes. Psycho-Oncology: 1997, 6, 302 310

version is a valid and reliable instrument and consists of one scale measuring state anxiety and another scale measuring trait anxiety (Van Der Ploeg et al., 1980). For research requiring repeated measures it is not unusual to select a few items (Ven Knippenberg et al., 1990). In this study the items $1,3,5$ and 17 from the state anxiety scale were used. These items are mentioned by Van der Ploeg et al. (1980) as suitable when a selection must be made.

The Dutch, shortened adaptation of the Profile of Mood States (McNair et al., 1971) was used for measuring mood disturbances. This valid and reliable instrument (Wald and Mellenbergh, 1990) consists of 32 items and has five dimensions: depression, anger, fatigue, vigour and strength.

Finally, patient files were used to gather information on sociodemographic data and length of hospitalization.

\section{Data collection procedures}

Patients were visited in the hospital (about 4.00 a.m.) the day before and two and four days after surgery. Data were derived from patients by the researcher using the questionnaires' formats.

Within the framework of the patient file audit, all relevant parts of the patient files were copied after the patients were discharged from the hospital.

\section{Statistical analyses}

For continuous data, differences in background characteristics were tested with ANOVA, while hierarchical loglinear analysis was used for categorical data. The two-sided significance level was fixed at 0.05 .

Effects on all patient outcomes were determined by ANCOVA for repeated measures.

Testing took place for the 'interaction between condition and measurement period' and for the 'interaction between condition, measurement period and patient category'.

Statistical adjustments were made for several covariates (see below Tables 2, 3 and 4), all combined in a multivariate confounder score (Miettinen, 1985). One-sided testing with a significance level of 0.05 was utilized for all outcome variables, because the programme was expected to result solely in positive effects.

Initially, data on the outcome variables 'State anxiety' and 'Mood disturbances' did not meet the ANCOVA's assumption of normality and therefore a square root and logarithmic transformation were respectively applied.

\section{RESULTS}

\section{Background characteristics}

There were no significant differences between colon cancer patients in the experimental condition and those in the control condition with respect to the following background characteristics: 'Sex', 'Age', ‘Type of surgery', and 'Hospital'. Neither were there significant differences between experimental and control breast cancer patients with respect to the background characteristics mentioned (see Table 1).

\section{[TABLE 1]}

\section{Postoperative pain}

Pain intensity. Pain intensity scores for postsurgical day 2 of patients in the experimental condition are lower after the programme than before; both in colon and breast cancer patients (see Table 2, and Figures 1 and 2). In other words, patients admitted after the CE programme had less intense pain on day 2 than comparable patients admitted before the program. There is a trend across the two measurement periods in the reverse direction in the control condition. 
Francke, A.L., Garssen, B., Luiken, J.B., Schepper, A.M.E. de, Grypdonck, M., Huijer Abu-Saad, $\mathrm{H}$. Effects of a nursing pain programme on patient outcomes. Psycho-Oncology: 1997, 6, 302 310

There are no obvious changes across the measurement periods in colon and breast cancer patients' pain intensity for day 4 in the experimental condition (see Table 2). However, there is some increase in colon cancer patients' pain intensity for day 4 in the control condition. Statistical testing reveals significant interaction between condition and measurement period (see Table 2), indicating a difference between experimental and control patients. It can therefore be concluded that the programme had a positive effect on pain intensity. The interaction involving patient category was not significant, indicating beneficial effects for both colon and breast cancer patients.

\section{[TABLE 2], [FIGURE 1] AND [FIGURE 2]}

Pain duration. On days 2 and 4, patients also indicated the number of hours of pain they had experienced during the previous day. Table 2 shows that, although scores vary over time, there is no significant difference between experimental and control patients. This indicates that the programme did not lead to a decrease in duration of pain.

Sleepless hours as a result of pain. Experimental and control patients did not differ with respect to the number of hours that pain kept them awake (see Table 2). This leads to the conclusion that the programme did not significantly affect the number of sleepless hours either.

\section{Psychological state}

State anxiety. Experimental colon and breast cancer patients' anxiety scores for days 2 and 4 are almost the same after the programme than before (see Table 3 ). There is no significant difference with patients in the control condition, indicating that the programme did not result in a decrease of patients' state anxiety.

Mood disturbances. The programme did not result in a decrease in mood disturbances either. This conclusion can be derived from the nonsignificant difference between patients in both conditions (see Table 3).

\section{[TABLE 3]}

\section{Length of hospitalization}

The length of hospitalization of colon and breast cancer patients' (computed from the day of surgery) varies considerably across the two measurement periods. There is, however, no significant difference between experimental and control patients (see Table 4), and the programme appears to have had no effect on length of hospitalization.

\section{[TABLE 4]}

\section{DISCUSSION}

The foregoing shows that the CE programme had a positive effect on surgical colon and breast cancer patients' pain intensity. However, it is not completely clear which changes in nurses' interventions are related to the decrease in patients' pain intensity. Other parts of the study revealed that the quality of nurses' psychosocial, physical and relaxation interventions, and the quality of nurses' analgesic administrations improved (Francke, 1996; Francke et al., 1996b and 1997). It is not very likely that effects on pain intensity are caused by quality improvements of psychosocial interventions, since there are no significant changes in state anxiety and mood disturbances. It seems more probable that quality improvements of either physical and relaxation interventions or analgesic administrations have resulted in less intense pain (Francke, 1996a).

No effects were established on duration of hospitalization. In this decade every patient is discharged from the hospital as soon as possible. It may therefore be too optimistic to expect significant changes on this outcome variable as a result of nurses participating in pain 
Francke, A.L., Garssen, B., Luiken, J.B., Schepper, A.M.E. de, Grypdonck, M., Huijer Abu-Saad, H. Effects of a nursing pain programme on patient outcomes. Psycho-Oncology: 1997, 6, 302 310

programmes. For future studies, alternative outcome variables related to patients' recovery process have to be searched for.

Despite the assessed decrease in pain intensity, patients' pain duration, and number of sleepless hours as a result of pain did not change significantly. Probably the changes in pain intensity were too moderate to have consequences for the other outcome variables.

Previous studies on the impact of pain CE programmes on patients (Degner et al., 1982; Foglesong, 1983; Foglesong et al., 1987; Sofaer, 1984) did not determine the number of sleepless hours as a result of pain, state anxiety, mood disturbances or duration of hospitalization, impeding comparisons with the study presented. Sofaer (1984) did, however, determine patients' pain intensity and duration. As in our study, Sofaer found no significant decrease in pain duration on day 2. Contrary to our findings, Safaer's did not indicate a significant decrease in pain intensity for day 2. Sofaer did, however, assess a significant decrease in pain intensity scores for the postoperative days 0 and 1 . It is not known if our programme had an equally positive effect on pain intensity scores for the first two postoperative days. No data were obtained from patients during these days to avoid extra burden immediately after surgery. Retrospective questions did not seem to be a useful alternative since patients in our sample found it difficult to remember the precise pain intensity for the immediate postoperative period.

Comparisons between our findings and those of other authors are also impeded by methodological differences. In contrast to our study, other pain CE studies which measured patient outcomes (Degner et al., 1982; Foglesong, 1983; Foglesong et al., 1987; Sofaer, 1984), did not include a control condition. However, limited insight is provided into the extent to which changes can be attributed to a CE programme without a control condition. Illustrative is that if no control condition had been involved in the study presented, the changes in pain duration (see Table 2) would have been incorrectly related to the programme. Furthermore, none of the aforementioned CE studies involving measurements among patients used statistical adjustment for confounding variables. The study presented illustrates that this procedure is valuable in promoting the internal validity of results. For example, the average scores in Table 4 show a considerable, unexpected increase in the duration of hospitalization of experimental patients undergoing colon surgery. However, the difference in trend proved to be insignificant when statistical adjustments were made for the type of surgery and other relevant variables. It is recommended that future studies also use control group designs and statistical adjustment for confounding variables. More insight into the effects of pain CE programmes on patient outcomes may then be gained.

Finally, a short comment on noncooperation of patients and how this may have affected the reliability of the data. As stated, patients were indirectly recruited through nurses. Nurses did not systematically inform us about patients who did not want to cooperate. However, nurses did suggest that the percentage of noncooperation was very low (probably less than $10 \%$ ). This indicates that the results are to a large extent representative for the population of surgical colon and breast cancer patients admitted to the five hospitals involved. However, because patients experiencing a high level of physical or psychological discomfort probably refused more often than patients with less discomfort there may be limited bias.

\section{REFERENCES}

Abbott, F.V., Gray-Donald, K., Sewitch, M.J., Johnston, C.C., Edgar, L. and Jeans, M.E. (1990) The prevalence of pain in hospitalized patients and resolution over six months. Pain, 50, 15-28.

Acute Pain Management Guideline Panel (1992) Acute pain management: operative or medical procedures and trauma. Clinical practice guideline. AHCPR Pub.: No.92-0032. Rockville, MD: Agency for Health Care Policy and Research, Public Health Service, U.S. Department of Health and Human Services.

Bonica, J.J. (1987) Importance of effective pain control. Acta Anesthesiol. Scand. 31, 1-16. 
Francke, A.L., Garssen, B., Luiken, J.B., Schepper, A.M.E. de, Grypdonck, M., Huijer Abu-Saad, $\mathrm{H}$. Effects of a nursing pain programme on patient outcomes. Psycho-Oncology: 1997, 6, 302 310

Carr, E.C.J. (1990) Post-operative pain: patients' expectations and experiences. J. Adv. Nurs. 15, 89-100.

Closs, S.J. (1990) An exploratory analysis of nurses' provision of postoperative analgesic drugs. J. Adv. Nurs., 15, 42-49.

Dalton, J.A. (1989) Nurses' perceptions of their pain assessment skills, pain management practices, and attitudes toward pain. Oncol. Nurs. Forum 16 (2), 225-231.

Daut, R.L. and Cleeland, C.S. (1982) The prevalence and severity of pain in cancer. Cancer, 50 1913-1918.

Degner, L., Fujii, S. and Levitt, M. (1982) Implementing a program to control chronic pain of malignant disease in an extended care facility. Cancer Nurs. 5 263-268.

Foglesong, D.H. (1983) The impact of a staff development offering on nursing practice. J. Contin. Educ. Nurs., 14 (6), 12-15.

Foglesong, D.H., Lambert, J. and Emerick, J. (1987) Variables which influence the effect of staff development on nursing practice. J. Contin. Educ. Nurs. 18 (5), 168-171.

Francke, A.L. (1996) Continuing pain education: the impact on nursing practice. PhD-thesis. Maastricht/ Utrecht.

Francke, A.L., Garssen, B. and Huijer Abu-Saad, H. (1996a) Continuing pain education in nursing: a literature review. Internat. J. Nurs. Stud., 33 (5), 567-578.

Francke, A.L., Luiken, J.B., Garssen, B., Huijer Abu- Saad, H. and Grypdonck, M. (1996b) Effects of a pain programme on nurses' psychosocial, physical and relaxation interventions. Patient Educ. Counsel. 28, 221-230.

Francke, A.L., Luiken, J.B., Garssen, B, Huijer Abu- Saad, H. and Grypdonck, M (1997) Effects of a continuing education program on nurses' pain assessment practices. J. Pain Sympt. Manage.

Grossman, S.A., Scheidler, V.R., Swedeen, K., Mucenski, J. and Piantadosi, S. (1991) Correlation of patient and caregiver ratings of cancer pain. J. Pain Sympt. Manage. 6 (2), 53-57.

Kloot, W.A. van der and Vertommen, H. (1989) De MPQ-DLV. Een standaard nederlandstalige versie van de McGill Pain Questionnaire. Achtergronden en handleiding. Swets and Zeitlinger, Lisse.

Knippenberg, F.C.E., Duivenvoorden, H.J., Bonke, B. and Passchier, J. (1990) Shortening the State-Trait Anxiety Inventory. J. Clin. Epidemiol., 43 (9), 995-1000.

McNair, D.M., Lorr, M. and Droppleman, L.F. (1971) Edits Manual for the Profile of Mood States. Educational and Industrial Testing Service, San Diego, California.

Melzack, R. (1975) The McGill pain questionnaire: major properties and scoring methods. Pain, 1, 277-299.

Miettinen, O.S. (1985) Theoretical Epidemiology; Principles of Occurrence Research in Medicine. Wiley, New York.

Paice, J.A., Mahon, S.M. and Faut-Callahan, M. (1991) Factors associated with adequate pain control in hospitalized postsurgical patients diagnosed with cancer. Cancer Nurs. 14 (6), 298-305.

Ploeg, H.M. van der, Defares, P.B. and Spielberger, C.D. (1980) Handleiding bij de ZelfBeoordelings Vragenlijst. Een nederlandstalige bewerking van de Spielberger State-Trait Anxiety Inventory. Swets and Zeitlinger, Lisse.

Scott, J. and Huskisson, E.C. (1976) Graphic representation of pain. Pain 2, 175-184.

Sofaer, B. (1984) The effect of focused education for nursing teams on postoperative pain of patients. Dissertation. University of Edinburgh, Edinburgh.

Spielberger, C.D., Gorsuch, R.L. and Lushene, R.E. (1970) Manual for the State-Trait Anxiety Inventory. Consulting Psychologists Press, Palo Alto, California.

Vanderiet, K., Adriaensen, H., Carton, H. and Vertommen, H. (1987) The McGill Pain Questionnaire constructed for the Dutch language (MPQ-DV). Preliminary data concerning reliability and validity. Pain, 30, 395-408.

Verkes, R.J., Vanderiet, K., Vertommen, H., Van der Kloot, W.A. and Van der Mey, J. (1989) De MPQDLV: een standaard Nederlandstalige versie van de McGill Pain Questionnaire voor België en Nederland, 1989. In: W.A. van der Kloot and H. Vertommen (eds.), De MPQ-DLV. Een standaard nederlandstalige versie van de McGill Pain Questionnaire (pp. 57-69). Swets and Zeitlinger, Lisse. 
Francke, A.L., Garssen, B., Luiken, J.B., Schepper, A.M.E. de, Grypdonck, M., Huijer Abu-Saad, $\mathrm{H}$. Effects of a nursing pain programme on patient outcomes. Psycho-Oncology: 1997, 6, 302 310

Wald, F.D.M. and Mellenbergh, G.J. (1990) De verkorte versie van de Nederlandse vertaling van de Profile of Mood States (POMS). Nederlands Tijdschr. Psychol. 45, 86-90.

\section{TABLES AND FIGURES}

Table 1. Comparisons between the groups of colon cancer patients, and comparisons between the groups of breast cancer patients distinguished, with respect to background characteristics

\begin{tabular}{|c|c|c|c|c|c|c|}
\hline & & \multicolumn{2}{|c|}{ Experimental condition } & \multicolumn{2}{|c|}{ Control condition } & \multirow[b]{2}{*}{ Testing } \\
\hline \multicolumn{2}{|c|}{$\begin{array}{l}\text { Background characteristics of } \\
\text { COLON patients }\end{array}$} & $\begin{array}{l}\text { Period M1 } \\
\quad(n=15)\end{array}$ & $\begin{array}{c}\text { Period M2 } \\
(n=11)\end{array}$ & $\begin{array}{l}\text { Period M1 } \\
\quad(n=15)\end{array}$ & $\begin{array}{l}\text { Period M2 } \\
\quad(n=13)\end{array}$ & \\
\hline \multirow[t]{2}{*}{ Sex } & female & 7 & 6 & 7 & 10 & $\begin{array}{l}\mathrm{LR} \chi^{2}=3.97 \\
\mathrm{df}=4\end{array}$ \\
\hline & male & 8 & 5 & 8 & 3 & $\mathrm{p}=0.41$ \\
\hline \multicolumn{2}{|l|}{$\begin{array}{l}\text { Age in years } \\
M(S D)\end{array}$} & $68.5(11)$ & $65.0(15)$ & $69.4(13)$ & $71.0(15)$ & $\begin{array}{l}\mathrm{F}=0.622 \\
\mathrm{df}=1\end{array}$ \\
\hline \multirow[t]{2}{*}{ Type of surgery } & resect* & 3 & 4 & 4 & 2 & $\begin{array}{l}p=0.43 \\
\mathrm{LR} \chi^{2}=1.97 \\
\mathrm{df}=4\end{array}$ \\
\hline & resec-* & 12 & 7 & 11 & 11 & $p=0.74$ \\
\hline \multirow[t]{6}{*}{ Hospital } & 1 & 1 & 2 & 4 & 4 & $\begin{array}{l}\mathrm{LR} \chi^{2}=12.40 \\
\mathrm{df}=13\end{array}$ \\
\hline & 2 & 3 & 3 & 1 & 2 & $p=0.49$ \\
\hline & 3 & 7 & 7 & 7 & 2 & \\
\hline & 4 & 3 & 3 & 1 & 3 & \\
\hline & 5 & 1 & 1 & 2 & 2 & \\
\hline & & Experim & ondition & Contro & adition & \\
\hline \multicolumn{2}{|c|}{$\begin{array}{l}\text { Background characteristics of } \\
\text { BREAST patients }\end{array}$} & $\begin{array}{c}\text { Period M1 } \\
(n=27)\end{array}$ & $\begin{array}{c}\text { Period M2 } \\
(n=30)\end{array}$ & $\begin{array}{c}\text { Period M1 } \\
(n=26)\end{array}$ & $\begin{array}{c}\text { Period M2 } \\
(n=15)\end{array}$ & Testing \\
\hline Sex & $\begin{array}{l}\text { female } \\
\text { male }\end{array}$ & $\begin{array}{r}27 \\
0\end{array}$ & $\begin{array}{r}30 \\
0\end{array}$ & $\begin{array}{r}26 \\
0\end{array}$ & $\begin{array}{r}15 \\
0\end{array}$ & Not applicable \\
\hline $\begin{array}{l}\text { Age in years } \\
M(S D)\end{array}$ & & $61.3(30)$ & $60.2(27)$ & $60.1(15)$ & $63.0(26)$ & $\begin{array}{l}\mathrm{F}=0.45 \\
\mathrm{df}=1 \\
p=0.51\end{array}$ \\
\hline \multirow[t]{3}{*}{ Type of surgery } & mast $+\dagger$ & 22 & 17 & 19 & 10 & LR $\chi^{2}=8.77$ \\
\hline & mast- $-\uparrow$ & 1 & 1 & 2 & 0 & $\begin{array}{l}\mathrm{df}=7 \\
p=0.27\end{array}$ \\
\hline & lump $+\dagger$ & 4 & 12 & 5 & 5 & \\
\hline \multirow[t]{5}{*}{ Hospital } & 1 & 6 & 4 & 7 & 3 & \multirow{5}{*}{$\begin{array}{l}\mathrm{LR} \chi^{2}=15.50 \\
\mathrm{df}=13 \\
p=0.28\end{array}$} \\
\hline & 2 & 7 & 6 & 6 & 2 & \\
\hline & 3 & 2 & 6 & 3 & 6 & \\
\hline & 4 & 3 & 6 & 6 & 2 & \\
\hline & 5 & 9 & 8 & 4 & 2 & \\
\hline
\end{tabular}

"resect=colon resection with colostomy; resec-=colon resection without colostomy.

$\nmid$ mast $+=$ mastectomy with lymph node resection; mast-=mastectomy without lymph node resection, lump+=lumpectomy with lymph node resection. 
Francke, A.L., Garssen, B., Luiken, J.B., Schepper, A.M.E. de, Grypdonck, M., Huijer Abu-Saad, H. Effects of a nursing pain programme on patient outcomes. Psycho-Oncology: 1997, 6, 302 310

Table 2. Mean scores on postsurgical 'Pain intensity', 'Pain duration', and 'Sleepless hours as a result of pain' (SDs are between brackets), tested with ANCOVA for repeated measures*

\begin{tabular}{|c|c|c|c|c|c|c|c|}
\hline & Category & Day & Condition & Period M1 & Period M2 & $\begin{array}{c}\text { Condition } \times \\
\text { period }\end{array}$ & $\begin{array}{c}\text { Condition } \times \\
\text { period } \times \\
\text { patient category }\end{array}$ \\
\hline $\begin{array}{l}\text { Pain intensity } \\
\text { (range: } \underline{0}-10)^{\dagger}\end{array}$ & $\begin{array}{l}\text { colon } \\
\text { breast }\end{array}$ & $\begin{array}{l}\text { day } 2 \\
\text { day } 4 \\
\text { day } 2 \\
\text { day } 4\end{array}$ & $\begin{array}{l}\text { exp. } \\
\text { cont. } \\
\text { exp. } \\
\text { cont. } \\
\text { exp. } \\
\text { cont. } \\
\text { exp. } \\
\text { cont. }\end{array}$ & $\begin{array}{l}3.3(2.3) \\
3.3(2.4) \\
2.3(2.3) \\
2.3(1.7) \\
2.8(2.4) \\
2.6(2.7) \\
1.7(2.3) \\
1.4(1.8)\end{array}$ & $\begin{array}{l}2.9(2.7) \\
4.7(2.5) \\
2.3(2.1) \\
3.1(2.9) \\
1.8(2.1) \\
3.1(3.0) \\
1.5(2.1) \\
1.2(1.9)\end{array}$ & $\begin{array}{l}\mathrm{F}=4.25 \\
\mathrm{df}=1 \\
p=0.02\end{array}$ & $\begin{array}{l}\mathrm{F}=0.00 \\
\mathrm{df}=1 \\
p=0.47\end{array}$ \\
\hline $\begin{array}{l}\text { Pain duration } \\
\text { (range: } \underline{0}-16)^{\dagger}\end{array}$ & $\begin{array}{l}\text { colon } \\
\text { breast }\end{array}$ & $\begin{array}{l}\text { day } 2 \\
\text { day } 4 \\
\text { day } 2 \\
\text { day } 4\end{array}$ & $\begin{array}{l}\text { exp. } \\
\text { cont. } \\
\text { exp. } \\
\text { cont. } \\
\text { exp. } \\
\text { cont. } \\
\text { exp. } \\
\text { cont. }\end{array}$ & $\begin{array}{r}12.1(5.6) \\
10.6(7.1) \\
8.2(6.9) \\
12.1(7.1) \\
9.5(7.2) \\
9.0(7.0) \\
7.2(6.9) \\
4.6(5.9)\end{array}$ & $\begin{array}{r}7.0(6.4) \\
9.9(7.0) \\
10.4(6.6) \\
9.6(6.6) \\
8.1(6.7) \\
8.3(6.7) \\
6.0(6.9) \\
5.1(6.4)\end{array}$ & $\begin{array}{l}\mathrm{F}=0.87 \\
\mathrm{df}=1 \\
p=0.18\end{array}$ & $\begin{array}{l}\mathrm{F}=0.03 \\
\mathrm{df}=1 \\
p=0.44\end{array}$ \\
\hline $\begin{array}{l}\text { Sleepless hours } \\
\text { (range: } \underline{0}-8)^{\dagger}\end{array}$ & $\begin{array}{l}\text { colon } \\
\text { breast }\end{array}$ & $\begin{array}{l}\text { day } 2 \\
\text { day } 4 \\
\text { day } 2 \\
\text { day } 4\end{array}$ & $\begin{array}{l}\text { exp. } \\
\text { cont. } \\
\text { exp. } \\
\text { cont. } \\
\text { exp. } \\
\text { cont. } \\
\text { exp. } \\
\text { cont. }\end{array}$ & $\begin{array}{l}0.5(1.1) \\
0.4(0.8) \\
0.5(1.1) \\
0.8(1.2) \\
0.6(1.0) \\
0.2(0.5) \\
0.2(0.6) \\
0.1(0.3)\end{array}$ & $\begin{array}{l}1.4(1.3) \\
1.0(1.3) \\
0.8(1.2) \\
0.7(1.1) \\
0.3(0.7) \\
0.7(1.0) \\
0.1(0.5) \\
0.6(0.9)\end{array}$ & $\begin{array}{l}\mathrm{F}=1.29 \\
\mathrm{df}=1 \\
p=0.13\end{array}$ & $\begin{array}{l}\mathrm{F}=2.53 \\
\mathrm{df}=1 \\
p=0.06\end{array}$ \\
\hline
\end{tabular}

"With statistical adjustment for 'Pain intensity soore for the day before surgery', 'State anxiety score for the day before surgery', 'Hospital', 'Type of surgery', 'Age', 'Sex' and 'Number of days in intensive care'.

"The most favorable scores are underlined.

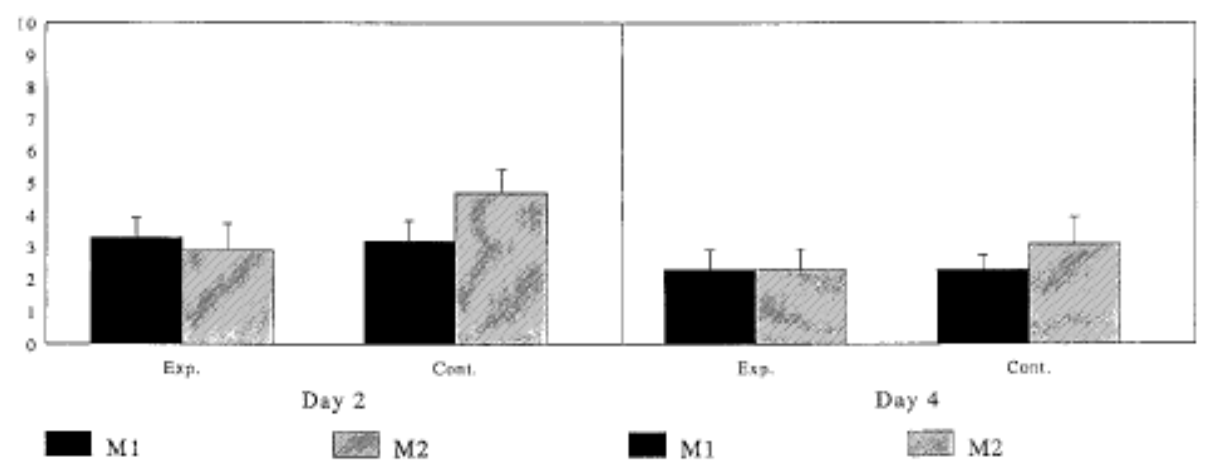

Figure 1. Mean pain int ensity (and standard error) for postsurgical days 2 and 4 in surgical colon cancer patients

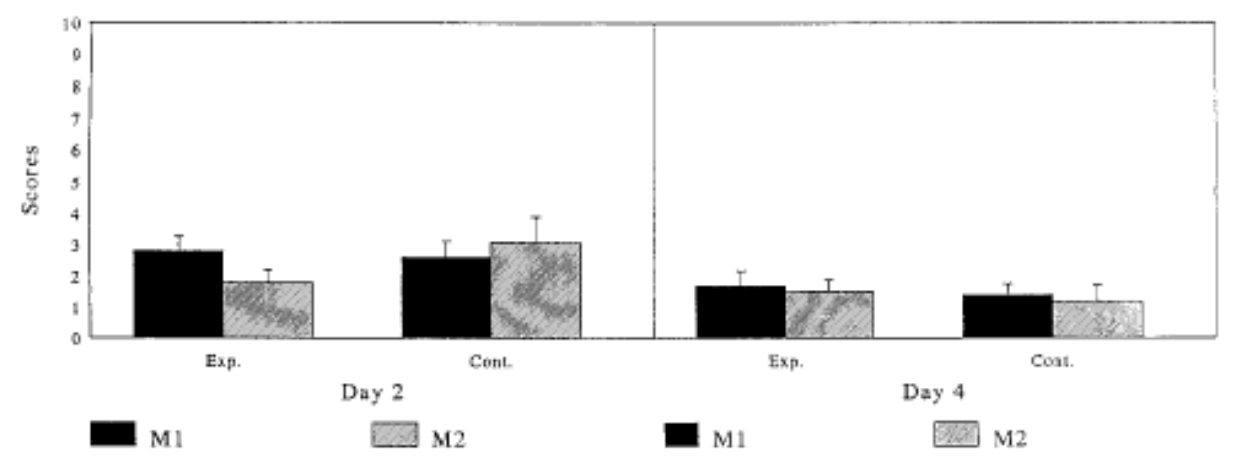

Figure 2. Mean pain intensity (and standard error) for postsurgical days 2 and 4 in surgical breast cancer patients 
Francke, A.L., Garssen, B., Luiken, J.B., Schepper, A.M.E. de, Grypdonck, M., Huijer Abu-Saad, $\mathrm{H}$. Effects of a nursing pain programme on patient outcomes. Psycho-Oncology: 1997, 6, 302 310

Table 3. Mean scores on state anxiety and mood disturbances (SDs are between brackets), tested with ANCOVA for repeated measures*

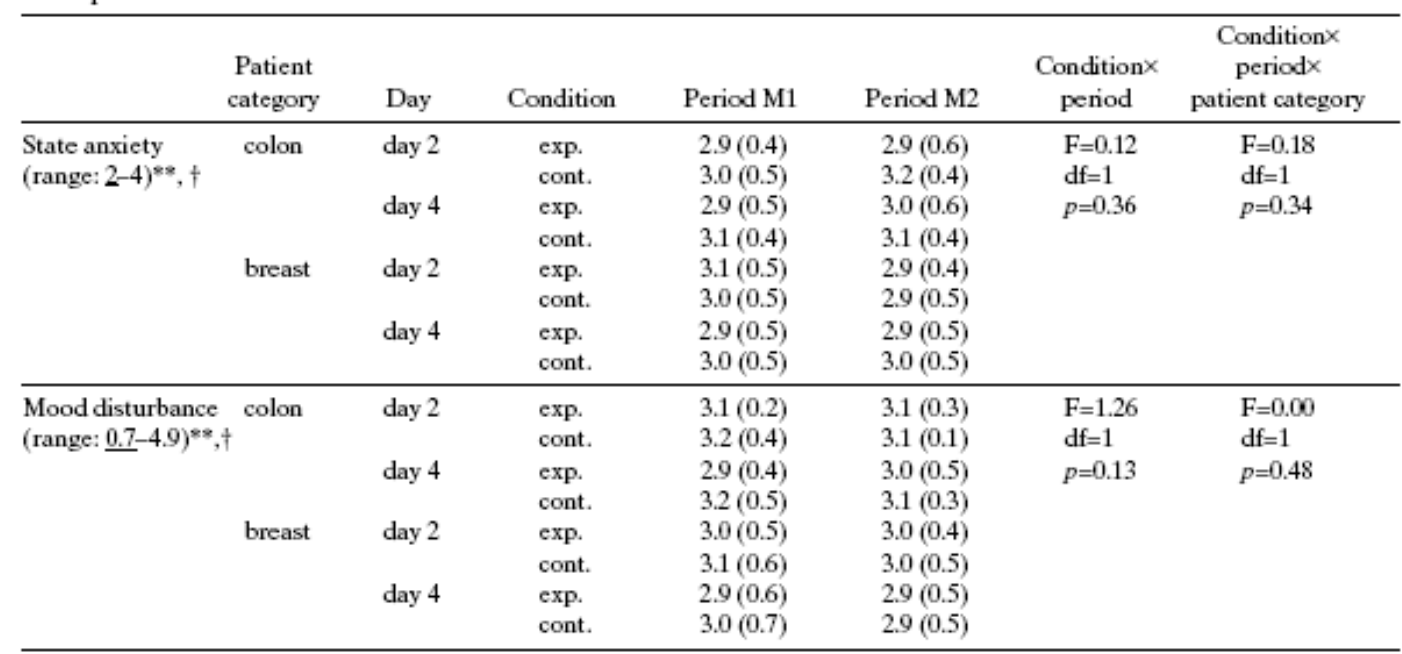

"With statistical adjustment for 'Pain int ensity soore for the day before surgery', 'State anxiety score for the day before surgery', 'Hospital', 'Type of surgery', 'Age', 'Sex' and 'Number of days in intensive care'.

\$ The most favorable scores are underlined.

† Square root transformed scores.

$\Varangle$ Logarithmic transformed scores.

Table 4. Mean scores on length of hospitalization (SDs are between brackets), tested with ANCOVA for repeated measures*

\begin{tabular}{|c|c|c|c|c|c|c|}
\hline & $\begin{array}{c}\text { Patient } \\
\text { category }\end{array}$ & Condition & Period M1 & Period M2 & $\begin{array}{l}\text { Condition } \times \\
\text { period }\end{array}$ & $\begin{array}{c}\text { Condition } x \\
\text { period } x \\
\text { patient category }\end{array}$ \\
\hline $\begin{array}{l}\text { Length of } \\
\text { hospitalization in }\end{array}$ & colon & $\begin{array}{l}\text { exp. } \\
\text { cont. }\end{array}$ & $\begin{array}{l}13.5(7.2) \\
14.3(6.3)\end{array}$ & $\begin{array}{l}16.0(8.2) \\
14.2(6.0)\end{array}$ & $\begin{array}{l}F=1.12 \\
d f=1\end{array}$ & $\begin{array}{l}\mathrm{F}=0.71 \\
\mathrm{df}=1\end{array}$ \\
\hline days & breast & $\begin{array}{l}\text { exp. } \\
\text { cont. }\end{array}$ & $\begin{array}{l}9.3(3.0) \\
9.3(3.4)\end{array}$ & $\begin{array}{l}8.8(3.5) \\
9.4(3.5)\end{array}$ & $p=0.15$ & $p=0.20$ \\
\hline
\end{tabular}

"With statistical adjustment for 'Pain int ensity score for the day before surgery', 'State anxiety score for the day before surgery', 'Hospital', 'Type of surgery', 'Age', 'Sex' and 'Number of days in intensive care'. 